\title{
Impact of Students' Interest on Learning Islamic Education among SMKA Students in Kuala Terengganu, Malaysia
}

\author{
Adamu Zakiyu Ubale ${ }^{1}$ \\ Naja'at Nasir ${ }^{1}$ \\ Abdul Hakim Abdullah² \\ ${ }^{1}$ Faculty Of Islamic Contemporary Studies, Universiti Sultan Zainal Abidin, Kuala Terengganu \\ Terengganu Malaysia; zakiyuadamu@gmail.com/najatnasir86@gmail.com \\ ${ }^{2}$ Research Institute of Islamic Products And Civilization/Faculty Of Islamic Contemporary Studies \\ Universiti Sultan Zainal Abidin, Kuala Terengganu, Terengganu Malaysia Hakimabd@unisza.edu.my
}

\author{
Doi:10.5901/mjss.2015.v6n6s1p105
}

\begin{abstract}
Muslim students are expected to have a profound interest in learning Islamic education so as to gain extreme understanding of their revealed religion. The study revealed that one of the factors affecting students' interest in learning Islamic education is parents' influence. The present study meant to identify the effect of pupils' interest in learning Islamic education and also determine the extent to which students' interest predict the learning performance of Islamic education among religious secondary schools' students in Kuala Terengganu Malaysia. The study adopted Quantitative approach; a survey type of descriptive study was employed. A questionnaire was distributed to a sample of 335 students attending the national religious secondary schools in Kuala Terengganu. The collected data was analysed using a statistical package for social science (SPSS) version 19. The findings revealed that students' interest in learning Islamic Education significantly predicts the learning performance of Islamic education at $=.802, p=.000$. Therefore, parents and teachers should use good inventive methods that will inspire students' interest in an effort to make learning of Islamic education more expressive to the learners.
\end{abstract}

Keywords: students' interest, learning, Islam, Islamic education, learning performance, parents, teachers, children, school.

\section{Introduction}

Academic attainment is stimulatingly a central issue of government, parents, teachers and community in general. Nowadays, the worry with the subject of refining academic performance has also improved. Research revealed a significant relationship between socio-psychological variables (such as; Interest, motivation and self-efficacy) and academic performance (Adeyemu, 2005). Interest is referred as a content-exact motivational distinctive formed of inherent sensation-related and worth-related valences. It often identified as one of the important motivational constructs that influence students' engagement and achievement in learning (Shen \& Chen, 2006). The findings from various studies point out the position of interest for the complexity of text comprehension, the practice of learning strategies, as well as the quality of the expressive experience while learning (Ulrich, 1991). Despite this, Zaiton and Salim (2012) indicate that one of the factors affecting students' interest in learning Islamic education is parent's influence, which prevents children from getting an adequate learning. Islam encourages parents to take good care about their children's education and other activities right from home up to the school environment and also urge them to strive to fulfil it. Children are trust given to the parent if parent fulfil the responsibility given to them will surely develop an interest to children on learning. So children's Islamic education is a task that Islam gave to parents where Islam promised a severe burden that the negligent will not even smell the fragrance of paradise rather to be among the dwellers. Despite the serious burden for their negligence, many parents nowadays failed to fulfil this responsibility in acquiring Islamic education to their children. Lack of parental involvement in learning Islamic education helps to create failure at school and negatively affect the interest as well as an incentive for children. Many students cannot learn effectively, and as a result of this perform poorly in school tests and examinations. The failure is not necessary as a result of their low intellectual inadequacies or lack of material or due to poor studies habits but probably because they have not been properly stimulated or aroused to develop an interest in learning. Base on this, the present study aimed to determine the impacts of students' interest in learning Islamic education as it found related positively to the learning outcomes. 


\section{Research Objectives}

1. To identify the effects of the students' interest in learning the performance of Islamic education.

2. To determine the extent to which students' interest predicts the Islamic education's performance.

\section{Research Hypothesis}

H0: There is no significant relationship between students' interest and learning performance of Islamic education.

\section{Significance of the Study}

Standing of this study pointed out how the findings of the painted problems or answers to the objectives influenced educational philosophy or practice. The study findings will increase the interest of the students through motivating them towards learning of Islamic education. It will also help parents as well as teachers to understand that interest is one of the great instrument that influences the learning achievement so as to enable them strive to develop it to the children.

\section{Concept of Interest}

Students' interest is assumed as a mental stand of commitment, skilful in the moment, and a tendency to involve constantly in specific notions, proceedings, or things over time. Various studies have revealed that students' interest in learning leads to a greater degree level of learning (Krapp, 2002). Psychologists were supported that interest were the most significant motivational influences in learning and improvement (Berlyne, 1949). The relationship amongst interest and learning has absorbed on three types of interest: they are individual, situational, and topic. Individual interest is measured to be an individual's tendency to join to certain stimuli, occasions, and matters. Situational interest is caused by certain features of the environment. These comprise content features such as human movement or life themes and physical features such as the ways in which responsibilities are prepared and presented. Topic interest, is the level of interest generated when a particular subject is obtainable, seems to have mutually individual and situational aspects (Ainley, Hidi, \& Berndorff, 2002). Researchers reviewing interest have concentrated mainly on two dissimilar concepts; individual and situational interest (Hidi, 1990; Hidi \& Baird, 1988 \& Krapp, 2002). The study revealed that interest has an influence on different facets of learning that encompasses the value of educational outcomes, the practice of learning tactics, and the excellence of the learning skill.

\section{Concept of Learning}

Learning entails grasping new experience and promoting a greater understanding of things not recognized to us and also about creating a better sense of our environments (Admin, 2012). It also defined as the relatively persistent change in an individual's behaviour as a result of experience or training (Masha, 2002). There are three major elements in research on learning namely; implicit learning and the brain, informal learning and design for formal learning and beyond. Alexandrer \& Winnie (2006) differentiate the three as follows; in implicit learning, information is learned naturally and sometimes without someone being aware of having acquired it, learning a language to young children is a good example of implicit learning. Informal learning usually takes place in the home environment, parks, museum, among peers, and in other locations where an intended and planned educational schedule is not commandingly sustained over time. For example ordinary learning in non-western values that do not involve formal education as recognised in ethnographic studies but also in the informal learning of mathematics in Western values. Design for formal learning and beyond denotes basically with learning from teaching in educational settings. It comprises the use of information on learning to make a design for formal learning and beyond and to study the effects of these designs to further inform theoretic development.

From the above one can understand that Learning is the performance of obtaining new or adjusting and strengthening, current knowledge, conducts, abilities, values and may encompass synthesizing different kinds of information. It is the procedure that remains all-time in the lives of human beings as long as there is aspiration and enthusiasm to learn. Three features formed what learning all about. The first one is that individual must be changed through learning; if there is no change in behaviour as a result of learning definitely indicates that learning does not effectively accomplished. Secondly, that through experience, changes should come about, this is because learning is influenced by experiences. Thirdly, the changes is in an individual's possible and positive behaviour, change in behaviour can be at relatively simple level as for example, when people learn to brush their teeth, or at more complicated level as 
for example when people try to appreciate a sculpture of drawing.

\section{Concept of Islamic Education}

Islamic education is regarded as a process that makes one be the complete person, including the rational, spiritual, and social dimensions as indicated by Al-attas (1979). Similarly, Islamic education is the process through which a person is given a training as well as preparation on how to adequately worship the almighty Allah so as to enjoy in the hereafter (Raoudhatul Firdausi \& Muhammad, 2013). Based on this, one will realise that Islamic education is a comprehensive and unique way of life which is fundamentally tailored to suit the divine purpose and fundamental goals for human existence on this globe. It also guides one towards the realisation of that divine purpose for their lives on earth as enshrined in the Qur'an and traditions of the Prophet Muhammad (May peace and blessings of Allah be upon him). The basic aim of the Islamic education is to enrich a Muslim with the necessary information on how to worship the Almighty Allah so as to live an honourable life. However, developing a person spiritually is one of the aims of Islamic education which enable one to live a harmonious life in the community. In an addendum to this, it aimed to make a balance between three level; sense, mind and ethics and make them improved through various educational approaches. When there is a balance between these three, one will have a better life that will lead him to sanctify a relationship between him and his creator (Sobhi, 2012). Islam give more emphasis on seeking knowledge that undoubtedly is the root principle of Islamic education, this will eventually connect one to the sense of truth which will give birth to the feeling of complete faith (iman) in the Lord of universe.

\section{Brief Related Literature Review}

In a longitudinal study carried out by Koller et al.., (2001) which entailed the secondary school students, it is discovered that interest in learning mathematics do not directly influence the learning attainment, but has influence on course work assortment and attainment. The study suggests that previous academic performance influences interest in learning mathematics subsequently. Results of correlation between interest and learning as well as achievements have also showed that interest built incentive have constructive effects on both the process and the outcome of academic learning. Similarly, Adeyemo (2005) in his report asserted an important prediction of educational performance by an interest in education. However, the study was conducted with a focus to identify the locus of control, interest in schooling and selfefficacy as predictors of academic performance among Junior Secondary School Students. The study participants involved five-hundred (500) students comprising three-hundred (300) boys and two-hundred (200) girls. Random sampling (stratified) techniques were employed to select the sample from twenty-five secondary schools. An ex-post facto study design was employed. Two research questions were established and responded. The findings point out that locus of control, interest in schooling and self-efficacy cooperatively and significantly helps to the prediction of the educational performance of the Junior Secondary School children (Adedeji, Adeyinka \& Olufemi, 2009). Supporting the previous study, Jose et al., (2009) conducted a study examining a relationship between motives, expectations, preparedness and academic performance. The data was gathered through Spanish version of the MEPU questionnaire, which was developed by Byrne and Flood (2007). The analysis revealed that Interest in the subject of accounting, the experience of the subject at school, and academic self-confidence as well as university access scores were all significantly correlated with performance. Moreover, the study was conducted predicting the effect of attitude as well as the interest of students on academic performance in science. Three instruments were applied to the study that includes Science oriented Attitude Scale (SOAS), Science Vocational Interest Inventory (SVII) and Achievement Test in Integrated Science (ATIS). The study is a quasi-experimental type. Thirty (30) forms 1 Junior Secondary School Students in Nigeria were selected as a sample for the study. Multiple regression was employed to analyse the predictable hypothesis. The findings indicated that Science Interest influenced the strongest strength for predicting academic performance than the attitude of the students in their different aptitude level group (Olufemi \& Gbore, 2012). Another study was conducted applying multiple prediction design to determine the extent of association and prediction of the students' interest in education and attitude to school independently and cooperatively on their educational attainment. The sample comprises of 518 respondents; it was selected using a stratified random sampling. Multiple regression was employed as a statistical tool for data analysis. Results revealed significant relationship and multiple predictions of children educational attainment with the forecaster variable (interest). It indicates a $21.60 \%$ of the variance in children educational attainment. Therefore, enhancement of children interest in learning and attitude to school might assists immensely to enhancing their achievment educationally ( Kpolovie et al.., 2014).

The present study is unique from the above mentioned studies. Many studies were conducted investigating a 
relationship and effects between students' interest and educational performance in the various school subjects such as mathematics and other science subjects but not on Islamic education. The current study meant to determine the effects as well as the extent to which students' interest predicts the Islamic education's performance.

\section{Methodology}

The study is a systematic study, intended to stimulate the improvement of education. A quantitative approach was employed; it encompassed using of numbers, numerical data, and statistic. The technique was carefully chosen considering the nature of the study as it involves using of numbers and numerical data as well as utilising a statistical tool for data analysis. A survey type of descriptive research has been adopted. It is a survey type of descriptive research because it was engaged to describe the effects as well as the extent to which students' interest predicts the learning performance of Islamic education. The questionnaire was utilised as an instrument for data collection. The researcher designed it for the purpose of this study. It measures in a straight line the level of students' interest towards Islamic education. In addition, students' scores on Islamic education have been collected and used to determine the level of students' performance in Islamic education as indicated by Sheldon (2009) that academic achievement is frequently measured by students' grades and their test performances. .

\subsection{Respondents}

Being that the target populations consist of five thousands two hundred and forty-two $(5,242)$, thefore, a sample size of the study comprised of three hundred and thirty-five (335) students (respondents). The sample was chosen from two national religious secondary schools namely; SMKA DATO HAJI ABBAS and SMKA SHEIKH ABDUL MALEK. The sample size was carried out by using the table for determining the sample size of Krejcie and Morgan (1970) with 95\% level of confidence. In the case of this study, the simple random technique was employed for selecting the research sample.

\subsection{Pilot study}

Exploratory factor analysis (EFA) and reliability in the survey was employed in the study to refine the items. To test the viability of questionnaires and method, a pilot study was run using small-scale from the target population. A total number of one hundred (100) respondents including male and female from the two selected schools were participated in the study. Participants were reported having found the items easy to understand. The result was presented below;

Table 1. Students' interest in learning Islamic education

\begin{tabular}{|c|c|c|c|c|c|c|}
\hline \multicolumn{7}{|c|}{ Students' Motivation in Learning Islamic Education } \\
\hline \multirow{5}{*}{$\begin{array}{l}\text { Number of items in the } \\
\text { construct before the pilot study } \\
\text { Nine (20) }\end{array}$} & $\begin{array}{c}\text { Corporate image } \\
\text { components }\end{array}$ & $\begin{array}{l}\text { No of } \\
\text { items }\end{array}$ & $\begin{array}{l}\text { Cronbach's } \\
\text { Alpha value }\end{array}$ & $\begin{array}{c}\text { Cronbach's Alpha } \\
\text { (standardized) }\end{array}$ & $\begin{array}{l}\text { KMO } \\
\text { Value }\end{array}$ & $\begin{array}{c}\text { Significance } \\
\text { level }\end{array}$ \\
\hline & Component 1 & 3 & .607 & .616 & \multirow{4}{*}{.779} & \multirow{4}{*}{.000} \\
\hline & Component 2 & 3 & .612 & .622 & & \\
\hline & Component 3 & 2 & .681 & .686 & & \\
\hline & Component 4 & 3 & .694 & .702 & & \\
\hline
\end{tabular}

From the above, it will become obviously that the table indicated that there is a number of twenty items under the construct (students' interest) before the pilot study carry out. Factor analysis extracted it after discarding the unreliable items into four distinct components based on the eigenvalue greater than 1.0. As revealed in the table there are three items under component 1 , three items under component 2, two items from component 3 , and three items under component 4. The cronbach's alpha value in component 1 is .616, in component 2.612 , in component 3.681 and .694 in component 4 . Therefore, the reliability measures have exceeded the least value of 0.6 as suggested by Nunally (1978). However, the KMO Value is .779 which exceeded the recommended value of 0.6 (Kaiser, 1974). Conversely, the Bartlett's test significance value is appropriate to the required value as it is 0.00 . However, it will become evidently that the items are now reduced to eleven items that will further continue to represent the twenty items of the construct in the primary research. In a nutshell, the output suggests that the construct with identified items under each component are now reliable and appropriate for use in the central research. 


\subsection{Data analysis and presentation}

Data analysis carries out when investigators want to summarize and represent data that have been collected in a dependable, accurate, reliable, correct, and right method (Mills, 2007). Regarding the present study, collected data have been analyzed and categorized using the quantitative method. The collected data was analysed employing a simple descriptive statistics and Multiple regressions through using a statistical package for social science known as (SPSS) version 19. Data collected were presented in table form for easier interpretation and to make it responsive to computation analysis.

\section{Findings of the Study}

The research objectives and hypothesis were addressed through descriptive statistic and multiple linear regressions. The results were presented below, starting with respondents' demographics' information followed by students' responses analysis.

\subsection{Respondents demoghraphic information}

The respondents used in this study comprised 335 students going to national religious secondary school (SMKA) in kuala terennganu characterised by gendar and age. Their demoghraphic's information is presented below;

Table 2. Students' Gender

\begin{tabular}{|c|c|c|}
\hline \multicolumn{3}{|c|}{ Students' Gender } \\
\hline Gender & Frequency & Percent \\
\hline MALE & 122 & $36.4 \%$ \\
\hline FEMALE & 213 & $63.6 \%$ \\
\hline Total & 335 & $100.0 \%$ \\
\hline
\end{tabular}

As shown in Table 2 above, the respondents (students) contained predominately 213 females representing (63.6\%) of the sample. However, 122 of the participants were male that cover (36.4\%) of the sample.

Table 3. Students' Age

\begin{tabular}{|c|c|c|}
\hline \multicolumn{3}{|c|}{ Students' Age } \\
\hline Age & Frequency & Percent \\
\hline 13 & 110 & $32.8 \%$ \\
\hline 14 & 125 & $37.3 \%$ \\
\hline 15 & 100 & $29.9 \%$ \\
\hline Total & 335 & $100.0 \%$ \\
\hline
\end{tabular}

Regarding the age, Table 3 revealed that 124 students representing (37.3\%) of the respondents are of 14 years old, and 110 students representing (32.8\%) are of 13 years old. Conversely, 100 students representing (29.9\%) in the sample are of 15 years old.

\subsection{Findings of the study and analysis}

The findings of the stated objectives and predicted hypothesis is summarized in table 4, table 5 , table 6 , table 7 and table 8. in addendum to the above, Table 4 contained the descriptive statistics of the variables and Table 5 is the correlation coefficient table whereby table 6 is the Regression Model Summary table. It is arranged for the $R, R^{2}$, adjusted $R^{2}$, and the standard error of the estimation, which can be utilized to conclude how well a regression model fits the data. This can be reached by looking at the entry labeled $\mathrm{R}$ square in the table. However, Table 7 is the statistical significance table. It examines whether the overall regression model is a good appropriate for the data. It can be attained by looking at the $F$ ratio in the ANOVA table. Table 8, that is the last table, is the estimated model coefficient. It is the overall form of the equation to forecast Islamic education's performance from the students' interest. 
Table 4. Descriptive statistics

\begin{tabular}{|l|c|c|c|}
\hline & Mean & st.Deviation & $\mathrm{N}$ \\
\hline Students' interest & 4.2638 & .42686 & 335 \\
\hline Islamic education's performance & 4.2955 & .56797 & 335 \\
\hline
\end{tabular}

Table 4 indicate the mean and standard deviation of the independent variable (students' interest) and dependent variable (Islamic education's performance) as well as the total number of the sample particularly selected for the study. The mean for students' interest is 4.2638 while for Islamic education's performance is 4.295 . The mean indicates the arithmetic average of the variables. However, the standard deviation measures the variability of each variable. From here, as one can see, the mean value of the independent variables is very close to the mean value of the dependent variable. It indicate how the variables relate to each other.

Table 5. The Relationship of students' interest and Islamic education's performance

\begin{tabular}{|l|c|c|c|}
\hline Variables & Islamic educations' performance & sig (2-tailed) & $\mathrm{N}$ \\
\hline Students' interest & $.603^{* *}$ & .000 & 335 \\
\hline
\end{tabular}

From the above table 5 , one can realize there was a high moderate positive correlation between students' interest and Islamic education's performance, $r=0.603, n=335, p=0.000 . P<.05$. This means increases in student's interest do significantly relate to increases in Islamic education's performance. Therefore, the analysis accepted to reject the study predicted null hypothesis.

Table 6. Regression coefficient-model of summary

a. Predictor: (Constant), students' interest

\begin{tabular}{|c|c|c|c|c|}
\hline Model & $\mathrm{R}$ & $\mathrm{R}^{2}$ & $\mathrm{R}^{2}$ adj & Std.error \\
\hline 1 & $.603 \mathrm{a}$ & .363 & .361 & .45394 \\
\hline
\end{tabular}

Table 6 indicates how the model fits the data. The $\mathrm{R}$ value signifies a multiple correlation that is 0.603 , this value revealed the strong correlation that show a good level prediction of the data. It also indicates a degree of the quality of the forecast of the islamic education's performance (dependent variable). However, R square (often called as coefficient of determination) that is .363 tells us the overall measure of the strength association. It is the quantity of variance contribution in the dependent variable (Islamic education's performance) which can be explained by the independent variable (students' interest). Therefore, can be concluding that students' interest is explaining approximately $36.3 \%$ of the variability of the dependent variable (Islamic education's performance).

Table 7. ANOVA summary of regression analysis

\begin{tabular}{l|l|c|c|c|}
\hline Model & df & F & P \\
\hline Regression & 1 & 189.867 & $.000 \mathrm{a}$ \\
\hline Residual & 333 & & \\
\hline Total & 334 & & \\
\hline
\end{tabular}

Table 7 displays that students' interest is statistically significantly forecast the dependent variable (Islamic education performance). The value is $F(1,333)=189.867, p<.000$, this means that the regression model is a good appropriate of the data. The result is evidently indicated that Islamic education's performance was significantly predicted by the students' interest. 
Table 8. Summary of regression variable predicting the Islamic education performance

Unstandardized Coefficient Standardized Coefficient
\begin{tabular}{|l|c|c|c|c|c|}
\hline Variables & B & std.error & $\beta$ & t & P \\
\hline Constant & .877 & .249 & & 3.517 & .000 \\
\hline Students' interest & .802 & .058 & .603 & 13.779 & .000 \\
\hline
\end{tabular}
**p<.01.

Table 8 indicates how the independent variable (students' interest) predicts dependent variable (Islamic education' performance). Unstandardized coefficients, point out how much the independent variable predicts the dependent variable holding the factor constant. Additionally, significant value in the table tests a statistical significance of the students' interest as it is extremely smaller than .05 . However, the result appeared with the following value; students' interest = $.802, p=.000$. This indicates that the value of Islamic education's performance will increase by the value of students' interest at .802 when the value of students' interest changed by 1 .

\section{Discussion of the Result}

The determination of the current study was to find out the effects as well as the extent to which students' interest predicts the Islamic education's performance. The findings denote that students' performance in Islamic education will be higher if they are highly interested and if they showed positive attitude as well as possessed good study habits. The result indicated a significant relationship between students' interest and Islamic education's performance, $r=0.603, n=335, p=$ 0.000 . $P<.05$ (see table 5), therefore, failed to accept the predictable hypothesis. However, the findings provided the following value; students' interest $=.802, p=.000$ (see table 8). It shows the extent to which independent variable (students' interest) predicts dependent variable (Islamic education's performance). This indicates that the value of Islamic education's performance will increase by the value of students' interest at .802 when the value of students' interest changed by unit. However, it can be concluding that students' interest is explaining approximately $36.3 \%$ of the variability of the dependent variable (Islamic education's performance). This indicated the effect of students' interest towards Islamic education. The result is an indicator of the fact that if a child develops an interest, it will enable him to put more effort into learning and consequently perform better in Islamic education.

In nutshell, the findings correspond with prior studies demonstrating the significance of self-interest towards academic performance. It supports the study report that asserted a significant prediction of academic performance by interest in education (Berlyne, 1949 \& Adeyemo, 2005). Moreover, result is in-line with the findings that asserted a significant relationship and multiple prediction of children academic achievement with the predictor students' interest. It further explains that enhancement of children interest in learning and attitude to school might assists immensely in enhancing their achievment educationally (Kpolovie et al., 2014). Result of the present study indicated that the more students become interested in their learning of Islamic education the better for their academic performance. It asserted that attitude towards education signifies a positive predisposition in the direction of schooling as well as every movement in the school setting, which might be intellectual, behavioural and or emotional. It also showed that learning Islamic education can be enhanced if the learning interest is managed by the students.

\section{Summary and Conclusion}

Base on the findings, the present study indicated a key role of interest in enhancing the academic performance. Regarding the correlation between the variables, the findings indicate a high moderate positive correlation between students' interest and Islamic education's performance. It asserted that increases in student's interest do significantly relate to increases in Islamic education's performance. However, the regression analysis indicates how the students' interest predicts the Islamic education's performance. It revealed that the value of Islamic education's performance will increase by the value of students' interest at .802 when the value of students' interest changed by 1 . It also point out that students' interest is explaining approximately $36.3 \%$ of the variability of the dependent variable (Islamic education's performance).

In conclusion, the result accepted to reject the study predicted null hypothesis as it discovered to have a significance correlation between the students' interest and Islamic education's performance. Based on this, it can be concluded that this study has certainly shown irresistible dominance of identified indication that children interest in learning as well as positive attitude predict Islamic education's performance. 


\section{Recommendations}

From the findings of the study, the following recommendations for practice and further investigations were suggested;

1. Teachers should use good inventive methods that will inspire students' interest in an effort to make learning of Islamic education more expressive to the learners and consequently should make the learning outcomes improved and will eventually change the attitude of the learners towards learning Islamic education.

2. A teacher as well as parents should consider the students' interest as utmost important. Therefore, they should strive tirelessly to improve it to children simultaneously. It should be through demonstration of the appropriate topics and developing ways of linking the contents to the real globe.

3. Further investigation should be directed to find out the students' interest mechanism on Islamic education and try to determine how each of them predicts the learning performance of Islamic education.

\section{References}

Adedeji, T., Adeyinka, T., \& Olufemi, A. (2009). Locus of control, interest in schooling, self-efficacy and academic achievement. Cypriot Journal of Educational Sciences, 4 (10), 168-182.

Adeyemo, D.A. (2005). Parental Involvement, Interest in Schooling and School Environment as Predictors of Academic Self-efficacy among Fresh Secondary School Students in Oyo State, Nigeria. Electronic Journal of Psychology of Education 5 (3), 1-15.

Ainley, M., Hidi, S., \& Berndorff, D. (1999, April). Situational and individual interest in cognitive and affective aspects of learning. Paper presented at the American Educational Research Association Meetings, Montreal, Quebec, Canada.

Al-Attas, M. N. (1979). Aims and objectives of Islamic education. 2ND Edition, Jeddah, Saudi Arabia: Hodder and Stoughton.

Alexandrer, P. \& Winnie, P. H. (2006). Hand book of educational psychology. $\left(2^{\text {nd }}\right.$ ed), New york. Lawrence Erlbaum Associates publishers.

Berlyne, D. E. (1949). Interest as a psychological concepts. The British journal of psychology, 38, 184-195.

Byrne, M. and Flood, B. (2007), "Exploring the antecedents of learning approaches: a study of international business students", The International Journal of Management Education, 6 (2), 44-62.

Olufemi, S. \& Gbore, L.O. (2012). Prediction of attitude and interest of science students of different ability on their academic performance in basic science, International Journal of Psychology and Counselling. 4(6), 68-72,

Hidi, S. (1990). Interest and its contribution as a mental resource for learning. Review of Educational Research, 60, 549-571.

Hidi, S., \& Baird, W. (1988). Strategies for increasing text-based interest and students' recall of expository texts. Reading Research Quarterly, 23, 465-483.

Jose L, A., Marann, B., Barbara, F. \& Jose Maria, G.(2009). Motives, expectations, preparedness and academic performance: a study of students of accounting at a spanish university. Revista de Contabilidad-Spanish Accounting Review, 12 (2), 279-300

Kaiser. (1974). In Awang zainuddin. (2012). Research methodology and data analysis. Second edition. penerbit press, university teknologi mara.

Koller, O., Baumert, J. \& Schnabel, K. (2001). Does interest matter? The Relationship between Academic Interest and Achievement in Mathematics. Journal for Research in Mathematics Education, 4(32), 448-470.

Kpolovie, P. J., Joe, A. I. \& Okoto, T. (2014). Academic Achievement Prediction: Role of Interest in Learning and Attitude towards School. International Journal of Humanities Social Sciences and Education, 1(11), 73-100.

Krapp A (2002) Structural and dynamic aspects of interest development: theoretical considerations from an ontogenetic perspective. Learning and Instruction, 12, 383-409.

Krejcie, R. V., \& Morgan, D. W. (1970). Determining sample size for research activities. Educational and Psychological Measurement. 30 (3): 607-610.

Masha, G. I. (2002). Human Learning. Kano, Rainbow Royale Publishers.

Mills, G. (2007). Action research: a guide for the teacher researcher, upper saddle river, pearson education.

Nunnally, J. (1978). Psychometric methods. (15t ed). New York: McGraw.

Raudlotul Firdaus, F.T., \& Muhammad, S. J. (2013). Islamic Education: The Philosophy, Aim, and Main Features. International Journal of Education and Research.1 (10), 1-18

Sheldon, S. B. (2009). In School, family, and community partnerships: Your handbook for action, (3rd ed). USA: Corwin Press.

Shen, B., \& Chen, A. (2006). Examining the interrelations among knowledge, interests, and learning strategies. Journal of Teaching in Physical Education, 25, 182-199.

Sobhi, R. (2012). IsImic philosophy of education. International journal of humanities and science. 2 (19), 150-157.

Ulrich, S. (1991). Interest, Learning and Motivation. (1st ed). Neubiberge, Institutional Repository of Potsdam University.

\section{Web references}

Admin.(2012).Difference between learning and performance. Google http://www.differencebetween.com/difference-between-learningand-vs-performance/\#ixzz3DV1aX109. Accessed on 28-july-2012. 